\title{
Logico-Semantic Relations of Raja Parhata Utterances in Saur Matua Ceremony
}

\author{
Mariati Nainggolan ${ }^{1}$, Morada \\ TETTY $^{2}$, FERIYANTI ELINA GULTOM ${ }^{3}$ \\ ${ }^{123}$ UNIVERSITAS NEGERI MEDAN
}

\begin{abstract}
This study aimed to identify the types of logico-semantic relations and the use of logico-semantic relations of Raja Parhata in the Saur Matua ceremony. This study was conducted by applying the descriptive qualitative method by Flick (2009). The source of data was Raja Parhata in the Saur Matua ceremony. The result of this research was types of logico-semantic relations can be found in Raja Parhata are paratactic elaboration (44,28\%), paratactic enhancement $(21,42 \%)$, hypotactic elaboration $(7,14 \%)$, paratactic extension $(11,42 \%)$, hypotactic enhancement $(12,85 \%)$, hypotactic extension (2,85\%). Moreover, the realization of logicosemantic relations in Raja Parhata's utterances mostly appears by using conjunction jadi (so), molo (if), and holani (that all), adverbial clause dungi (after that), verb baen (play), and preposition tu (to).
\end{abstract}

Keywords: Logico-semantic relations, raja parhata, saur matua ceremony 


\section{INTRODUCTION}

Logico-semantic relation refers to the meaning between paratactic and hypotactic relations; it is about the relationship between or among clauses in representing ideas. The logicosemantic relations also have the realization with a conjunction, adverb, etc. This relation is both logical and semantic. Halliday (2014:611) defines logico-semantic manifested in the system of conjunction into the two elements, expansion and projection of clause complexing. The logicosemantic relation is very varied since it represents how the speaker sees the connection between clauses. Logico-semantic relation indicates the meaning formed when a clause is combined with another in a clause complex.

Saur Matua ceremony is spiritual maturation in their customs and religion. This was realized because the Batak people could gather with the entire extended family in the Saur Matua ceremony. The idea of spiritual maturity they got after reflecting on the saur matua ceremony became a form of thanksgiving from all children and grandchildren who died to God, not again to ancestral spirits.

Saur Matua is the condition of someone who died superbly well, and the dead man has children and grandchildren. Saur refers to completeness or perfection, and it is believed that people who died were perfect in kinship, had children and grandkids. So, if the deceased's kinship was flawless, the traditional burial ceremony went off without a hitch (Saur Matua). However, if it had been a perfect death, it must be made perfect in that event, called ulaon na gok (event with full Custom). Ulaon na gok implemented maralaman (on the house yard). The prepared boan (food) is sigagat duhut (buffalo). They are present, united, and have gathered to deliver the bodies to their ultimate resting place.

\section{REVIEW OF LITERATURE}

\section{Logico-Semantic Relation}

Logico-semantic relation refers to the meaning between paratactic and hypotactic relations; it is about the relationship between or among clauses in representing ideas. The logico-semantic relations also have the realization with conjunction, adverb, Etc. This relation is both logical and semantic. Halliday (2014:611) defines logico-semantic manifested in the system of conjunction into the two elements, expansion and projection of clause complexing. The logico-semantic relation is very varied since it represents how the speaker sees the connection between clauses. Logico-semantic relation indicates the meaning formed when a clause is combined with another in a clause complex. 


\subsection{Expansion}

Expansion relates phenomena as being of the same order of experience. Expansion refers to the secondary clause expands the primary clause, by elaborating it, extanding it or enhancing it Halliday (2014:443).

\subsubsection{Elaboration}

In elaboration, one statement clarifies or describes the meaning more- the equal status sign (=) represents elaboration. The secondary clause does not add a new element to the image; instead, it adds a descriptive attribute or comment to the existing one, restating, clarifying, refining, or restarting it. Both paratactic and hypotactic elaboration is possible. Happy Holidays, Halliday! (2014:461)

a. Paratactic elaboration

Paratactic elaboration $(1=2)$, the relationship may be made explicit by conjunctive expressions such as or (rather), in other words, that is to say or I mean; or, in writing. Halliday (2004:397) divides paratactic elaboration specifically into three categories, exposition, exemplification, and clarification. Exposition, here the secondary clause restates the thesis of the primary clause in different words, to present it from another point of view, or perhaps just to reinforce the message. For example, each argument was fatal to the other; both could not be accepted.

\section{b. Hypotactic elaboration}

Hypotactic elaboration $(\alpha=\beta)$, Halliday(2004:399) states that it is the combination of elaboration with hypotactic gives the category of non-defining relative clause (also called 'nonrestrictive', 'descriptive'). The dependent clause in non-defining clause may be either finite or non-finite. In finite hypotactic elaboration, the dominant clause elaborates the meaning of independent clause in non-defining relative clause. Furthermore, the finite hypotactic elaboration includes clauses which have domain of time or place which indicated by when or where, for example, We need a cooling period, when the problems are becoming less important. 


\subsubsection{Extension}

Halliday (2014:471) In extension, one clause extends the meaning of another by adding something new to it. What is added may be just an edition, or else a replacement, or an alternative. There is a closer parallel with extension between paratactic and hypotactic than with elaboration; it can operate with a single system of categories for both kinds of taxis, although there are certain gaps in the paradigm. The relationship of extension is marked with (+). Extension may be either paratactic or hypotactic.

\section{a. Paratactic extension}

Paratactic extension is marked with $1+2$. In a paratactic extension the clauses in a nexus are linked together by conjunctions and, or, but. Thus, Thompson (2014:196) remarks 'paratactic extension covers most of what is traditionally called coordination'.

The semantic distinctions among and, but, or and so are summarized as: and is additive, indicating addition and sometimes chronological or logical sequence; but is adversative indicating a contrast of some kind; or is disjunctive, signaling alternation: and so is consequential, indicating a cause-effect type of relation Bloor (2004:175).

\section{b. Hypotactic extension}

Hypotactic extension is symbolized as $\alpha+\beta$. Hypotactic extension of this type can be recognized through the use of conjunctions while or whereas. In this case, the meaning is 'addition with contrast' Thompson (2014:197).

The hypotactic is also divided these two types but is limited to dependent clause. Moreover in finite hypotactic extension the dependent clause is marked by whereas, while, except, that, but, etc.

\subsubsection{Enhancement}

Enhancement is the logical relationship in clause complex which concerns with circumstantial information. Halliday (2014:476) states that in enhancement one clause (or sub complex) enhances the meaning of another by qualifying it in one of a number of possible ways: by reference to time, place, manner, cause or condition. Enhancement may be either paratactic and hypotactic. 
a. Paratactic Enhancement

The combination of enhancement with parataxis yields what is also a kind of co-ordination but with a circumstantial feature incorporated into it; the most frequently occuring subtypes are those of time and clause. The circumstantial feature is typically expressed: (a) by the conjunctions then, so, for, but, yet, still; (b) by a conjunction group with and: and then, and there, and thus, and so, and yet; or (c) by and in combination with a conjunctive such as at that time, soon afterwards, till then, in that case, in that way. Note also that some conjunctives, such as meanwhile, otherwise, therefore, however, nevertheless, are extending their use in modern spoken English Halliday (2004:413).

\section{b. Hypotactic Enhancement}

Hypotactic Enhancement $\left(\begin{array}{lll}\alpha & \mathrm{x}\end{array}\right)$ is the combination of enhancement with hypotactic gives what are known in traditional formal grammar as 'adverbial clauses'. Typically, hypotactically enhancing chains are limited to two clauses, with one clause (or sub-complex).

Hypotactically enhancing clauses may be finite or non-finite. The finite ones are introduced by a binder ('subordinating conjunction'). The non-finite are introduced either by a preposition such as on, with, by functioning conjunctively- note that sometimes the same word is both conjunction and conjunctive preposition, for example before, after; or by one of a subset of the binders- there are a few of these, such as when, which can function also with a non-finite clause Halliday (2004:416).

\subsection{Projection}

Halliday (2014:509) Projection refers to the secondary clause is projected through the primary clause, which instates it as a locution or an idea. The relationship of projection is clearly very different from the expansion; for one thing, it is always an essential part of the meaning of a projected that projected Thompson (2014:201). Projection compries two kinds of relations, locution and idea which are described as follows : 
Halliday (2014:510) states locution is one clause is projected through another, which present it is a locution, a construction of wording. Locution or projection of wording uses verbal processes (what is said) such as say, tell and ask. Specifically, the verbal process includes that of saying, commanding, asking and offering. Locution using double quotation as marks ("). Locution may be either paratactic and hypotactic.

\section{a. Paratactic Locution}

In paratactic locution, the linguistic experience is projected as quoting. Double quatation marks (") is used to signal the projected clause in paratactic locution.

b. Hypotactic Locution

The linguistic experience in hypotactic locution is projecting as meaning or mostly known as reporting. Bloor and Bloor (2004:195) state that hypotactic locution discusses reported/indirect speech in terms of functions sayer and reported.

\subsubsection{Idea}

Halliday (2014:511) defines idea as projection of meaning which uses 'mental' clause-what is thought which refer to verbs indicating perception, cognition, affection, and desire. In other word it is related to psychological matters. The verbs indicating mental processes include think, imply, wonder, reflect, want, whish, surmise, etc. The relationship of idea is marked with single quote ('). Idea may be either paratactic or hypotactic.

\section{a. Paratactic Idea}

According to Halliday (2004:456) paratactic idea indicates the same linguistic experience as paratactic locution that is quoting but in this case mental processes are used.

The paratactic idea is marked with 1'2. Only certain mental process verbs are regularly used to quote in this way, such as think, wonder, reflect, and surmise. 
While hypotactic idea indicates linguistic experience which is preojected as reporting by using mental processes. Like the hypotactic locution clauses in hypotactic idea whether projected or projecting clauses are also irreversible. The relationship of hypotactic idea is symbolized as $\alpha ’ \beta$.

\section{Realization of Logical Semantic Relation}

The realization of logical semantic relation in combining the clause complexes are follows

\section{a. Conjunction}

A conjunction is a word which marely together sentences, and sometimes words. Conjunction join together sentences and often make them more compact. The are three types of conjunctions are subordinating conjunctions (after, because, if that, though, although, till, before, unless, when, where, while), coordinating conjunctions (and, but, for, or nor, also) and correlative conjunctions ( either-or, neither-nor, both-and, toughtyet, whether, not only-but also). Wren and Martin (1978:206)

Example : John reads a book, and she summarizes it.

\section{b. Preposition}

A preposition is a word or group of words that is used with a noun, pronoun, or noun phraseto show direction, location, or time, or to introduce an object. A preposition used to connect a noun or pronoun to a verb or adjective in a sentence, a preposition word like in, to, for, out of. Preposition divided into preposition of place (in/into, on/onto, down, under, near, away from, beside, behind, in from of, round, againts, between, beyond), prepositions of time (at, on, in, during, over, for, since, till/untill, by, from, between). Eastwood (1994:293)

Example : Annisah reads a book, before she is going to school.

\section{c. Prepositional Phrase}

A prepositional pharase is a group of words including a preposition and a noun or its equivalent.

Example: Annisah reads a book, in addition her work quite a lot.

\section{d. Verb}


Eastwood (1994:76) says that verb is the main component of a predicate. Without it, there won't be a sentence, just a bunch of words with an incomplete thought. In other words verb is a part of speech which is used to demonstrate an action or a state of being. The verbs have the following forms namely, regular verb (arrive, arrived, arrived) an irregular verb (break, broke, broken). The finite and non-finite verbs, a finite verb phrase can come in a main clause or a sub clause example : The police took action. While a nonfinite verbs comes only in a sub clause example: We wanted the place to take action.

Example: Annisah reads a book, her work appears as well

\section{f. Adverbial Clause}

Eastwood (1994:334) An adverbial clause is part of the main clause in the same way as other adverbials are, such as an adverb or prepositional phrase. The clause usually goes in front position or end position. The order of clauses depends on what is new and important information. Adverbial clauses divided in to three types namely, clause of time ( while, after that, whenever/every time, just as, As soon/Immediately), clause of reason (seeing (that), now (that), because of, due to, in view of, on account of).

\section{Culture of Batak Toba}

This tribe has many wisdom expressions like proverbs, pantuns, philosophies, poetry of songs and others. There are many wise expressions in Batak Toba people. The wise expression is not less important and the value of life for human compared with a wise expression for other nation tribe. A wise expression is born from a truly expression and the struggle of an ancestors life from the past to present.

Pakpahan (2007:35) explained the meanings that contained in Batak Toba literature closely related with life which experienced everyday, like; Philosophy of life (Batak : Habisuhon), morality (Batak : Hahormaton), living rules (Batak : Adat dohot Uhum) and society (Batak : Parngoluon Siganup Ari). When examined carefully, a wisdom expression called Umpama, that exists in Batak Toba culture have four important place. The division are :

1. Philosophy (Batak : Umpama na marisi habisuhon means, sayings that contain knowledge or wisdom)

2. Ethical Courtesy (Batak : Umpama hahormaton means, sayings honor)

3. Rules (Batak : Umpama na mardomu tu adat dohot uhum means, sayings that contain about tradition and law)

4. Society (Batak : Umpama na mardomu tu parsaoran si ganup ari, ima na dipangke di tingki pesta, partamueon means, sayings that contain about daily intercourse, which is 
used in a party, visiting family, etc.)

According to Pakpahan (2007 : 38) One of Batak Toba dances is Tor-tor. People say, Tortor came from 'tor-tor', of 'tor-tor' the sound of the dancers' feet on the floor of Batak traditional house. The purpose of this dance was to celebrate of death, harvest, healing, and young party. This dance has ritual processes that must be followed.

\section{Batak Toba Death Ceremony}

Somebody is death in the context of traditional Batak Toba is the truth, everyone must pass away, and it is warranted by all religions. In addition to those noted above, there are still other types of death in Batak Toba, such as martilaha/tilahaon (who has not married), mate mangkar (dead husbands or wives, but have not descent), matipul ulu (husband or wife dies with children are still small), and matompas tutoru. Lothar Schereiner (1978; 1951).

And according to Simbolon (1981: 39) there are 3 kinds of death ceremonies as follows:

1. Sarimatua

Sari matua are those dead husbands or wives whose children are married but still has 1 or 2 children have not married yet (hot ripe).

2. Saurmatua

Saur matua is that his/her all children have got married and then he/she has also got grandchildren. Someone called saur matua, is when he/she has passed away in a position titir maranak (have sons), titirmarboru (have daughters), marpahompu sian anak baua (have grandchildren from the sons), marpahompu sian boru (have grandchildren from the daughters). As usual called in Batak Toba hagabeon to describe above.

3. Mauli bulung

Mauli bulung, is someone who died in a position titir maranak ( have sons), titir marboru (have daughters), marpahompu sian anak (have grandchildren from the sons), marpahompu sian boru (have grandchildren from the daughters), sahat namar-nini, sahat tu namar-nono and the possibility to marondok-ondok.

Mauli bulung has the age reached until 90 years old even longer than it, in terms of generations. Those who achieved mauli bulung are very rare nowdays. In Batak Toba traditions, the bodies who are mauli bulung were laid straight with both hands parallel to the body in the coffin.

\section{Raja Parhata}

Batak Toba saur matua ceremony has master of ceremony, the function is to lead the 
process of ceremony. Pakpahan (2007:135) states that Raja Parhata in Batak Toba ceremony has a very important role in the implementation of traditional events. A Raja Parhata must be understand the customary law and its application. A Raja Parhata must be understand all the intricacies of the Batak customs in general and the customs that apply their families in particular. To be Raja Parhata he must be able to distinguish the language when talking to his interlocutor. Someone can become a hula-hula and on the other hand can become boru, or dongan sabutuha. In an ulaon (traditional event) it is very important to know our position when marhata whether as dongan tubu, hula-hula, boru, raja naginokhon, raja panungkun, and raja pangalusi.

\section{RESEARCH METHODOLOGY}

According to Flick (2009:46), qualitative research is mainly concerned with the production and analysis of texts, such as transcripts and other analytic materials. In this research, the descriptive qualitative design was used to analyze the types of logico-semantic relations and how they were used in Batak Toba Saur Matua ceremony by Raja Parhata's utterances. The steps of collecting data are described as following: (1) Watching video Batak Toba saur matua ceremony, (2) Transcribing the utterances of Raja Parhata in saur matua ceremony, (3) Separating the utterances of Raja Parhata in saur matua ceremony into clauses.

The data of the study were taken from all clause complexes found in Raja Parhata utterances in Saur Matua ceremony. The source of data was taken from a Batak video that contains of Raja Parhata. The utterances were found in Batak Toba Saur Matua ceremony. For all clause complexes were analyzed based on the logico-semantic relations theory. According to the theory above, the researcher formulated the techniques of analyzing data as following : (1) Identifying clause complexes of Raja Parhata in saur matua ceremony, (2) Determining the kinds of logico-semantic relations, (3) Tabulating the kinds of logico-semantic into table, (4) Describing the finding to know how Raja Parhata uses the kinds of logicosemantic relations.

\section{FINDINGS AND DISCUSSIONS}

\section{Findings}

Based on the systemic functional linguistics (SFL) theory by Halliday 2014, the types of logico-semantic relations which were found in the utterances of Raja Parhata are paratactic elaboration, hypotactic elaboration, paratactic extension, hypotactic extension, paratactic enhancement and hypotactic enhancement. Only six of ten types of logico-semantic relations found in Raja Parhata utterances meanwhile four types that were missing are paratactic locution, hypotactic locution, paratactic idea and hypotactic idea.

From six types of logico-semantic relations which were used in Raja Parhata utterances, there mostly used to relate one clause to another is conjunction, adverbial clause, verb and preposition. The conjunctions that related the clause in utterances were are jadi (so), molo (if), and holani (that all), the adverbial clause that used were dung $i$ (after that), the verb that used is baen 
(play) and preposition $t u$ (to).

\section{Discussions}

The result of this study indicated that there were six of ten types of logico- semantic relations found, they were paratactic elaboration, hypotactic elaboration, paratactic extension, hypotactic extension, paratactic enhancement, and hypotactic enhancement. While there were four types which were not found namely paratactic locution, hypotactic locution, paratactic idea and hypotactic idea.

In delivering information, the speaker should concern with language used. The speaker should use the appropriate word to convey the messages therefore, the speaker's idea should be irrelated and sound logic. In all of Raja Parhata utterances, he presents his ideas mostly used the equality of relationship that is paratactic. It means that he links his ideas in the same status he uses the independent clause in the utterances which are combined by conjunction, verb and adverbial clause.

From six of logico-semantic relations types which are used by Raja Parhata utterances, paratactic elaboration mostly occurs in relating one clause to another clauses. Raja Parhata explained his ideas by using coordination conjunction, adverbial clause, verb and preposition which indicates clarification, cause and effect, variation, circumtantial time and clause. Meanwhile four types that are missing are paratactic locution, hypotactic locution, paratactic idea and hypotactic idea. It means that Raja Parhata doesn't need to quote other people's idea in conveying his utterances because Raja Parhata as the master ceremony that leads the role of saur matua ceremony, and uses the words that are appropriate by circumtantial time and cause, and also clarifiying words to make the audiences can follow the role of saur matua ceremony.

The findings of this study are very useful for speaker in representing ideas. They need to know logico-semantic relations in relating one clause with another. By knowing logico-semantic relations, speaker can arrange the information or messages. So the speaker's ideas can be organized in order that listeners get the understanding and the meaning of information.

\section{CONCLUSIONS AND SUGGESTIONS}

\section{Conclusions}

After analyzing logico-semantic relations in Raja Parhata's utterances the following conclusions were drawn : Only six of ten types of logico-semantic relations that found in Raja Parhata's utterances they are paratactic elaboration (31 utterances, 44,28\%), hypotactic 
elaboration (5 utterances, 7,14\%), paratactic extension (8 utterances, 11,42\%), hypotactic extension (2 utterances, 2,85\%),paratactic enhancement (15 utterances, 21,42\%), and hypotactic enhancement ( 9 utterances, 12,85\%). Meanwhile, there are three types that are missing are paratactic locution, hypotactic locution, paratactic idea, and hypotactic idea. The use of logicosemantic relations in Raja Parhata's utterances mostly appears by using conjunction, adverbial clause,verb and preposition.

\section{Suggestion}

In relation to the conclusions above, suggestions were drawn as the following :

The findings of this study can be used to describe a better understanding about logicosemantic relations for English students, the result of this study is suggested to be used as references for researchers who will conduct the same researches using logico-semantic relations theory, this study is suggested to readers who want to get more information about logico-semantic relations.

\section{REFERENCES}

Anggara. 2015. Tactic System And Logico-Semantic Relations Of Clause Complexes In Asean Free Trade Area (AFTA) Agreement. Semarang: Dian Nuswantoro University.

Bloor, Thomas \& Mariel. 2004. The Functional Analysis of English ( $2^{\text {nd }}$ ed.). London: Hodder Arnold.

Donald, Ary et al. 2018. Introduction to Research in Education (Tenth Edition). Canada: Wadsworth Publishing.

Flick, U. 2009. An Introduction to Qualitative Research London: SAGE Publications.

Gerot, L and Wignell. 1994. Making Sense of Functional Grammar. Sydney: Gerd Stabler.

Halliday, M., \& Matthiessen, C. 2004. An Introduction to Functional Grammar ( $3^{\text {rd }}$ ed.). London: Hodder Arnold.

Halliday, M., \& Matthiessen, C. 2014. An Introduction to Functional Grammar ( $4^{\text {rd }}$ ed.) USA: Routledge.

Martin, J.R., Matthiessen, C., \& Painter C. 1997. Working With Functional Grammar. Great Britain : Hodder Headline Group.

Muliani. 2015. Logico-Semantic Relation In Sri Mulyani Indrawati Speech.

Faculty Languages and Arts. Medan: State University of Medan.

Pakpahan.Mangala. 2007. Hikayat Datu Ramot Pakpahan. Jakarta : Untuk Kalangan Sendiri. 
Rahmah. 2013. Functional Grammar: Universitas Negeri Medan.

Saragih, A. 2014. Discourse Analysis: A Study on Discourse Based on Systemic Functional Linguistic Theory. Medan: Universitas Negeri Medan.

Thompson, G. 2014. Introducing Functional Grammar (3 $3^{\text {rd }}$ ed.). New York : Routledge.

Wahid. 2013. The Logico-Semantic Relation in The Skripsi Background of

Qualitative and Quantitative Research of English Education

Department of Maria Kudus University in 2012. 